Correspondence

Jongsik Chun

jchun@snu.ac.kr

\section{Sphingopyxis marina sp. nov. and Sphingopyxis litoris sp. nov., isolated from seawater}

\author{
Bong-Soo Kim, ${ }^{1}$ Young Woon $\mathrm{Lim}^{2}$ and Jongsik Chun ${ }^{1}$
}

\author{
${ }^{1}$ School of Biological Sciences and Institute of Microbiology, Seoul National University, Seoul 151- \\ 742, Republic of Korea \\ ${ }^{2}$ Division of Non-vascular Plants (Fungi/Algae), National Institute of Biological Resource, Incheon \\ 404-708, Republic of Korea
}

\begin{abstract}
Two yellow-pigmented, Gram-negative, aerobic bacterial strains, designated FR1087 ${ }^{\top}$ and FR1093 ${ }^{\top}$, were isolated from surface seawater off Jeju Island, Republic of Korea. Both strains required sea salts for growth. Phylogenetic analysis based on 16S rRNA gene sequences indicated that the two isolates belong to the genus Sphingopyxis, showing the highest level of sequence similarity with respect to Sphingopyxis flavimaris $\mathrm{SW}-151^{\top}(97.9 \%)$. The two isolates shared $98.5 \%$ sequence similarity. DNA-DNA hybridization between the isolates and the type strain of Sphingopyxis flavimaris clearly suggested that strains $\mathrm{FR} 1087^{\top}$ and $\mathrm{FR} 1093^{\top}$ represent $^{2}$ two separate novel species in the genus Sphingopyxis. Several phenotypic characteristics served to differentiate these two isolates from recognized members of the genus Sphingopyxis. The data from the polyphasic study presented here indicated that strains $F R 1087^{\top}$ and $F R 1093^{\top}$ should be classified as representing novel species in the genus Sphingopyxis, for which the names Sphingopyxis marina sp. nov. and Sphingopyxis litoris sp. nov., respectively, are proposed. The type strain of Sphingopyxis marina sp. nov. is FR1087 ${ }^{\top}\left(=\mathrm{IMSNU} 14132^{\top}=\mathrm{KCTC} 12763^{\top}=\mathrm{JCM}\right.$ $14161^{\top}$ ) and the type strain of Sphingopyxis litoris sp. nov. is FR1093 ${ }^{\top}$ (=IMSNU $14133^{\top}=$ KCTC $12764^{\top}=J C M 14162^{\top}$ ).
\end{abstract}

Members of the genus Sphingopyxis are Gram-negative, non-fermentative, aerobic, non-spore-forming, yellowpigmented or whitish-brown, motile and contain sphingoglycolipids. Takeuchi et al. (2001) proposed that Sphingomonas species should be divided into four different genera, namely Sphingobium, Novosphingobium, Sphingopyxis and Sphingomonas. The nomenclatural system of Takeuchi et al. (2001) has been generally accepted and used (Yabuuchi et al., 2002; Busse et al., 2003; Godoy et al., 2003; Yoon et al., 2005). In this study, we isolated two bacterial strains, designated FR $1087^{\mathrm{T}}$ and FR $1093^{\mathrm{T}}$, from seawater and subjected them to a polyphasic analysis. The strains clearly differed from recognized Sphingopyxis species and from each other and therefore represent two novel species of the genus Sphingopyxis.

Strains FR $1087^{\mathrm{T}}$ and $\mathrm{FR} 1093^{\mathrm{T}}$ were isolated from a sample of coastal surface seawater collected off Jeju Island, Republic of Korea. The seawater sample was diluted with sterilized artificial seawater (Lyman \& Fleming, 1940), spread onto a plate that contained marine agar 2216 (MA; Difco) and incubated at $30{ }^{\circ} \mathrm{C}$. The isolates were routinely

The GenBank/EMBL/DDBJ accession numbers for the $16 \mathrm{~S}$ rRNA gene sequences of strains $\mathrm{FR} 1087^{\top}$ and $\mathrm{FR} 1093^{\top}$ are $\mathrm{DQ781320}$ and DQ781321, respectively. cultured on MA and maintained as a glycerol suspension $(20 \%, \mathrm{w} / \mathrm{v})$ at $-80{ }^{\circ} \mathrm{C}$.

The 16S rRNA gene was amplified from a single colony by means of PCR with Taq polymerase (Takara). The PCR amplification and sequencing were performed as described previously (Chun \& Goodfellow, 1995). The pairwise sequence similarity values were determined using the EzTaxon server (Chun et al., 2007). The regions available for all sequences (positions 47-1437; Escherichia coli numbering system) were used to construct the phylogenetic trees after the exclusion of ambiguous positions (positions 67-84). Phylogenetic analyses were performed by following the same procedure as that described previously by Yi et al. (2005), using jPHYDIT (Jeon et al., 2005; available at http://chunlab.snu.ac.kr/jphydit/) and PAUP 4.0 (Swofford, 1998). Phylogenetic trees were inferred using the maximum-likelihood (Felsenstein, 1981), maximum-parsimony (Fitch, 1971) and neighbour-joining (Saitou \& Nei, 1987) methods. The resultant tree topologies were evaluated by means of bootstrap analyses (Felsenstein, 1985) based on 1000 resamplings.

Sequence comparisons with $16 \mathrm{~S}$ rRNA gene sequences held in GenBank indicated that the two isolates were closely related to the genus Sphingopyxis. Strains FR $1087^{\mathrm{T}}$ and FR $1093^{\mathrm{T}}$ had a sequence similarity of $98.5 \%$. Sphingopyxis 
Table 1. Phenotypic characteristics that serve to differentiate strains FR $1087^{\top}$ and FR $1093^{\top}$ from recognized Sphingopyxis species

Taxa: 1, strain FR1087 ; 2, strain FR1093 ${ }^{\mathrm{T}}$; 3, Sphingopyxis flavimaris; 4, Sphingopyxis baekryungensis; 5, Sphingopyxis macrogoltabida; 6, Sphingopyxis terrae; 7, Sphingopyxis alaskensis; 8, Sphingopyxis chilensis; 9, Sphingopyxis witflariensis; 10, Sphingopyxis taejonensis. The Escherichia coli numbering system was used for nucleotide signatures of the 16S rRNA gene. Data were taken from this study and from Godoy et al. (2003), Kämpfer et al. (2002), Lee et al. (2001), Takeuchi et al. (1993), Vancanneyt et al. (2001), Yoon et al. (2005) and Yoon \& Oh (2005). +, Positive; -, negative; w, weakly positive; v, variable; ND, not determined. Data in parentheses are for the type strain.

\begin{tabular}{|c|c|c|c|c|c|c|c|c|c|c|}
\hline Characteristic & 1 & 2 & 3 & 4 & 5 & 6 & 7 & 8 & 9 & 10 \\
\hline Colony colour & Yellow & Yellow & Yellow & Orange & $\begin{array}{l}\text { Whitish } \\
\text { brown or } \\
\text { yellow }\end{array}$ & $\begin{array}{c}\text { Light or } \\
\text { deep yellow }\end{array}$ & $\begin{array}{l}\text { Yellow to } \\
\text { beige }\end{array}$ & Yellow & Yellow & $\begin{array}{c}\text { Pale } \\
\text { yellow }\end{array}$ \\
\hline Motility & + & + & + & + & + & $\mathrm{v}(+)$ & + & + & + & + \\
\hline $\begin{array}{l}\text { Reduction of } \\
\text { nitrate to nitrite }\end{array}$ & - & - & - & + & - & - & - & - & - & - \\
\hline \multicolumn{6}{|l|}{ Hydrolysis of: } & & & & & \\
\hline $\begin{array}{l}\text { Aescumn } \\
\text { Gelatin }\end{array}$ & $\begin{array}{l}w \\
+\end{array}$ & $\begin{array}{l}\text { W } \\
-\end{array}$ & - & $\begin{array}{l}+ \\
-\end{array}$ & $\begin{array}{l}\mathrm{v}(+) \\
\mathrm{v}(-)\end{array}$ & $\begin{array}{c}\mathrm{V}(-) \\
-\end{array}$ & $\begin{array}{l}+ \\
-\end{array}$ & $\begin{array}{l}+ \\
-\end{array}$ & $\begin{array}{l}- \\
-\end{array}$ & - \\
\hline Urea & + & + & - & - & - & - & $\mathrm{v}(+)$ & - & - & - \\
\hline \multicolumn{11}{|l|}{ Utilization of: } \\
\hline D-Glucose & + & - & + & + & $(+)$ & $(-)$ & + & + & + & ND \\
\hline Malate & + & + & - & $\mathrm{w}$ & - & + & + & + & - & + \\
\hline Maltose & - & - & - & - & + & + & + & + & + & - \\
\hline Mannose & - & - & - & + & - & - & - & + & - & - \\
\hline \multicolumn{11}{|c|}{ Nucleotide signatures of $16 \mathrm{~S}$ rRNA gene } \\
\hline 134 & A & A & A & G & G & G & G & G & G & G \\
\hline $990: 1215$ & $\mathrm{U}: \mathrm{A}$ & $\mathrm{U}: \mathrm{A}$ & $\mathrm{U}: \mathrm{A}$ & $\mathrm{U}: \mathrm{A}$ & $\mathrm{U}: \mathrm{G}$ & $\mathrm{U}: \mathrm{G}$ & $\mathrm{U}: \mathrm{G}$ & $\mathrm{U}: \mathrm{G}$ & $\mathrm{U}: \mathrm{A}$ & $\mathrm{U}: \mathrm{G}$ \\
\hline Major polyamine ${ }^{*}$ & S, A & S & $\mathrm{ND}$ & ND & s & S & $\mathrm{ND}$ & S & S & ND \\
\hline Major fatty acids & $\begin{array}{c}\mathrm{C}_{17: 0} \\
\mathrm{C}_{17: 1} \omega 8 c, \\
\mathrm{C}_{17: 1} \omega 6 c, \\
\mathrm{C}_{18: 1} \omega 7 c\end{array}$ & $\begin{array}{c}\mathrm{C}_{18: 1} \omega 7 c, \\
\text { iso- } \mathrm{C}_{15: 0} \\
2-\mathrm{OH} / \\
\mathrm{C}_{16: 1} \omega 7 c\end{array}$ & $\begin{array}{c}\mathrm{C}_{18: 1} \omega 7 c \\
\text { iso- } \mathrm{C}_{15: 0} \\
2-\mathrm{OH} / \\
\mathrm{C}_{16: 1} \omega 7 c \\
\mathrm{C}_{17: 1} \omega 6 c\end{array}$ & $\begin{array}{l}\mathrm{C}_{18: 1} \omega 7 c \\
\mathrm{C}_{17: 1} \omega 6 c\end{array}$ & $\begin{array}{c}\mathrm{C}_{18: 1} \omega 7 c, \\
\text { iso- } \mathrm{C}_{15: 0} \\
2-\mathrm{OH} / \\
\mathrm{C}_{16: 1} \omega 7 c\end{array}$ & $\begin{array}{l}\mathrm{C}_{17: 1} \omega 6 c \\
\mathrm{C}_{18: 1} \omega 7 c\end{array}$ & $\begin{array}{l}\mathrm{C}_{17: 1} \omega 6 c \\
\mathrm{C}_{18: 1} \omega 7 c\end{array}$ & $\begin{array}{l}\mathrm{C}_{18: 1} \omega 7 c \\
\mathrm{C}_{17: 1} \omega 6 c\end{array}$ & $\begin{array}{c}\mathrm{C}_{17: 1} \omega 6 c, \\
\text { iso- } \mathrm{C}_{15: 0} \\
2-\mathrm{OH} / \\
\mathrm{C}_{16: 1} \omega 7 c\end{array}$ & $\begin{array}{c}\mathrm{C}_{18: 1} \omega 7 \mathrm{cl} \\
\mathrm{C}_{18: 1} \omega 9 t / \\
\mathrm{C}_{18: 1} \omega 12 t, \\
\mathrm{C}_{16: 0}\end{array}$ \\
\hline
\end{tabular}

${ }^{*}$ A, Agmatine; s, spermidine.

flavimaris showed the highest level of $16 \mathrm{~S}$ rRNA gene sequence similarity with respect to strains $\mathrm{FR} 1087^{\mathrm{T}}$ and FR $1093^{\mathrm{T}}$ (97.9\% for both). Out of five signature nucleotides defined for the genus Sphingopyxis (Takeuchi et al., 2001), three were found in the two isolates. They, along with Sphingopyxis flavimaris, lacked the remaining two signature nucleotides (Table 1).

The levels of sequence similarity between strain FR $1087^{\mathrm{T}}$ and other Sphingopyxis species were in the range 92.8$93.7 \%$ and the corresponding values for strain FR $1093^{\mathrm{T}}$ were $91.8-93.1 \%$. The neighbour-joining tree showed that the two isolates formed a monophyletic clade with the type strain of Sphingopyxis flavimaris (Fig. 1), with $100 \%$ bootstrap support. This relationship was confirmed by all other tree-inferring methods used in this study.

The close taxonomic relationship, i.e. the high levels of $16 \mathrm{~S}$ rRNA gene sequence similarity among strains FR $1087^{\mathrm{T}}$ and FR $1093^{\mathrm{T}}$ and Sphingopyxis flavimaris SW- $151^{\mathrm{T}}$, led us to employ DNA-DNA relatedness experiments to obtain further genomic comparisons (Stackebrandt \& Goebel,
1994). Genomic relatedness was determined using a Cary 300 Bio model UV/VIS spectrophotometer equipped with a Peltier-thermostatted $6 \times 6$ multicell changer and a temperature controller (Varian). The experimental details for the DNA-DNA hybridization studies were as described elsewhere (Yi \& Chun, 2006). The level of genomic relatedness observed between Sphingopyxis flavimaris and strain $\mathrm{FR} 1087^{\mathrm{T}}$ was $21.2 \%$, while that between Sphingopyxis flavimaris and strain $\mathrm{FR} 1093^{\mathrm{T}}$ was $36.3 \%$. The two isolates shared a low DNA-DNA relatedness value $(20.7 \%)$. All of these values are below the threshold $(70 \%)$ for determining bacterial species (Wayne et al., 1987); the finding strongly suggested that the two isolates belonged to novel genomic species in the genus Sphingopyxis.

Growth under anaerobic conditions was checked in an anaerobic chamber on MA and on nitrate-supplemented MA, both of which had been prepared anaerobically under nitrogen gas. Growth at various concentrations of $\mathrm{NaCl}$ and sea salts was investigated using sea-salt-free ZoBell's agar [ZoBell, 1941; $15 \mathrm{~g}$ Bacto agar (Difco), $5 \mathrm{~g}$ Bacto 


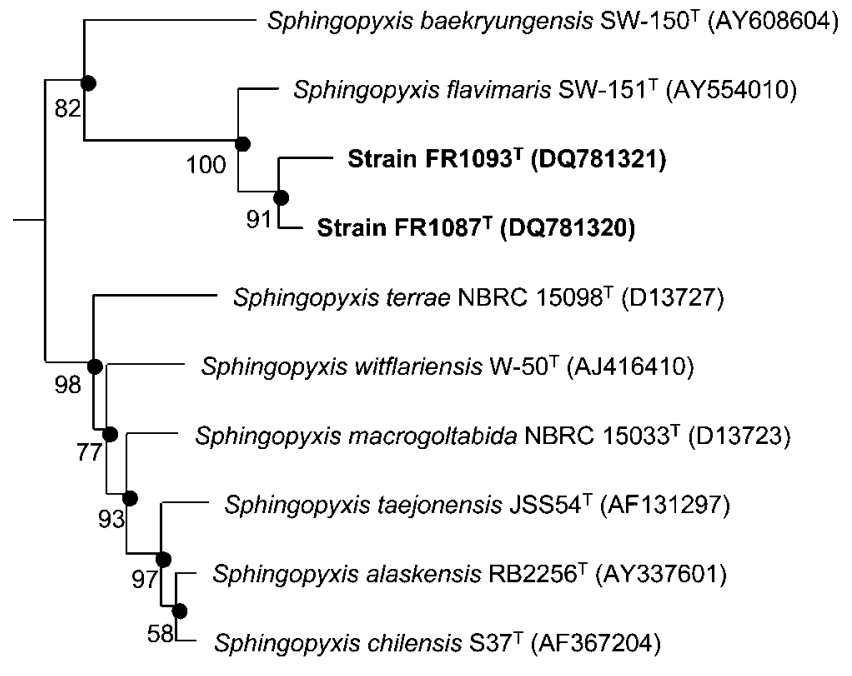

0.1

Fig. 1. Neighbour-joining phylogenetic tree for the genus Sphingopyxis, showing the positions of strains FR $1087^{\top}$ and FR1093 ${ }^{\top}$. Bootstrap percentages (based on 1000 resampled datasets) are shown at nodes when greater than $50 \%$. Filled circles indicate that the corresponding nodes (groupings) were also recovered in maximum-likelihood and maximum-parsimony trees. Helicobacter pylori ATCC $43504^{\top}$ (GenBank accession no. U01330) was used as the outgroup (not shown). Bar, 0.1 nucleotide substitutions per position.

peptone (Difco), $1 \mathrm{~g}$ yeast extract, $0.1 \mathrm{~g}$ ferric citrate in $1 \mathrm{l}$ distilled water]. The temperature range for growth was determined optically using a temperature gradient incubator (TVS 126MA; Advantec) with marine broth 2216 (Difco) and temperatures of $4-45{ }^{\circ} \mathrm{C}$ (specifically at 4.0, $10.0,15.1,18.3,21.2,23.7,26.5,29.0,31.8,34.4,37.3,40.7$ and $45{ }^{\circ} \mathrm{C}$ ). Biochemical tests were performed using API 20NE and API ZYM kits (bioMérieux): the strips were each inoculated with a heavy bacterial suspension in artificial seawater or AUX medium (bioMérieux) supplemented with $2 \%(\mathrm{w} / \mathrm{v})$ sea salts. Hydrolysis of casein, starch, Tween 80, hypoxanthine, tyrosine and xanthine was tested on MA using the substrate concentrations described by Cowan \& Steel (1965). The two isolates showed differences in terms of the hydrolysis of gelatin and the utilization of glucose. Both isolates utilized urea, unlike other phylogenetic neighbours. The results of the biochemical and physiological tests are given in the species description and are shown in Table 1.

Cellular fatty acids from the test strains were analysed by GLC according to the instructions of the Microbial Identification System (MIDI). For analysis of the cellular fatty acid methyl esters, cells were grown on MA at $30{ }^{\circ} \mathrm{C}$ for 6 days. The two strains differed substantially in terms of their major fatty acids: details are given in the species description and are shown in Table 1. Polar lipids were extracted using the procedures described by Minnikin et al.
(1984) and were identified by using two-dimensional TLC followed by spraying with the appropriate detection reagents (Komagata \& Suzuki, 1987). Sphingoglycolipid was found as a major polar lipid in both isolates. Polyamines were extracted and analysed according to the methods of Busse et al. (1989) and Flores \& Galston (1982). Strain FR $1087^{\mathrm{T}}$ contained spermidine $[8.6 \mu \mathrm{mol}$ (g dry $\left.\mathrm{wt})^{-1}\right]$ and agmatine $\left[4 \mu \mathrm{mol}(\mathrm{g} \text { dry } \mathrm{wt})^{-1}\right]$ as major components, whereas strain $\mathrm{FR} 1093^{\mathrm{T}}$ contained only spermidine $\left[17.78 \mu \mathrm{mol}(\mathrm{g} \text { dry } \mathrm{wt})^{-1}\right]$ as the major component.

On the basis of the data from the polyphasic study presented here, it is evident that strains FR $1087^{\mathrm{T}}$ and FR $1093^{\mathrm{T}}$ represent separate novel species in the genus Sphingopyxis, for which the names Sphingopyxis marina sp. nov. and Sphingopyxis litoris sp. nov., respectively, are proposed.

\section{Description of Sphingopyxis marina sp. nov.}

Sphingopyxis marina (ma.ri'na. L. fem. adj. marina of the sea, marine).

Gram-negative and aerobic. Oxidase-positive. Colonies are circular, convex and yellow in colour and $0.7-1.0 \mathrm{~mm}$ in diameter after cultivation for 6 days at $30{ }^{\circ} \mathrm{C}$ on MA. Spores are not formed. Does not grow without sea salts. Grows at 3-7\% (w/v) sea salts (optimum, 3-5\%) and 15$34.4{ }^{\circ} \mathrm{C}$ (optimum, 23.7-31.8 ${ }^{\circ} \mathrm{C}$ ). Does not grow under anaerobic conditions on MA or MA supplemented with nitrate. Tyrosine is hydrolysed, but Tween 80, starch, xanthine, hypoxanthine and casein are not. Positive reactions are obtained for arginine dihydrolase, urease, protease and the assimilation of glucose, arabinose, adipate, malate and citrate. Weakly positive for $\beta$ glucosidase (with API 20NE). With API ZYM, positive reactions are obtained for alkaline phosphatase, leucine arylamidase and trypsin, weakly positive reactions are obtained for esterase (C4), esterase lipase (C8), lipase (C14), valine arylamidase, cystine arylamidase, $\alpha$-chymotrypsin, acid phosphatase and naphthol-AS-BI-phosphohydrolase and negative reactions are obtained for $\alpha$ galactosidase, $\beta$-galactosidase, $\beta$-glucuronidase, $\alpha$-glucosidase, $\beta$-glucosidase, $N$-acetyl- $\beta$-glucosaminidase, $\alpha$-mannosidase and $\alpha$-fucosidase. Sphingoglycolipid is present as the major polar lipid. Major fatty acids are $\mathrm{C}_{17: 0}(20.5 \%)$, $\mathrm{C}_{17: 1} \omega 8 c(15.38 \%), \mathrm{C}_{17: 1} \omega 6 c(14.04 \%)$ and $\mathrm{C}_{18: 1} \omega 7 c$ $(13.6 \%)$. Spermidine and agmatine are present as major polyamine compounds, whereas cadaverine, putrescine and spermine are detected only in small amounts.

The type strain, FR $1087^{\mathrm{T}} \quad\left(=\mathrm{IMSNU} \quad 14132^{\mathrm{T}}=\mathrm{KCTC}\right.$ $12763^{\mathrm{T}}=$ JCM $14161^{\mathrm{T}}$ ), was isolated from surface seawater collected off Jeju Island, Republic of Korea.

\section{Description of Sphingopyxis litoris sp. nov.}

Sphingopyxis litoris (li.to'ris. L. gen. n. litoris of the seashore, of the coast). 
Gram-negative and aerobic. Oxidase- and catalasepositive. Colonies are circular, convex and yellow in colour and $0.7-1.0 \mathrm{~mm}$ in diameter after 6 days cultivation at $30{ }^{\circ} \mathrm{C}$ on MA. Spores are not formed. Does not grow without sea salts. Grows at $2-7 \%(\mathrm{w} / \mathrm{v})$ sea salts (optimum, 3-5\%) and $15-34.4{ }^{\circ} \mathrm{C}$ (optimum, 23.7$31.8^{\circ} \mathrm{C}$ ). Does not grow under anaerobic conditions on MA or MA supplemented with nitrate. Tyrosine and starch are hydrolysed, but Tween 80, xanthine, hypoxanthine and casein are not. Positive reactions are obtained for arginine dihydrolase, urease, $\beta$-galactosidase and assimilation of malate and citrate. Weakly positive for $\beta$-glucosidase (with API 20NE). With API ZYM, positive reactions are obtained for alkaline phosphatase, leucine arylamidase, esterase lipase (C8), trypsin and naphthol-AS-BI-phosphohydrolase, weakly positive reactions are obtained for esterase (C4), lipase (C14), valine arylamidase, cystine arylamidase, $\alpha$-chymotrypsin, acid phosphatase, $\alpha$-galactosidase and $\alpha$-glucosidase and negative reactions are obtained for $\beta$-galactosidase, $\beta$-glucuronidase, $\beta$-glucosidase, $N$-acetyl- $\beta$-glucosaminidase, $\alpha$ mannosidase and $\alpha$-fucosidase. Sphingoglycolipid is present as the major polar lipid. Major cellular fatty acids are $\mathrm{C}_{18: 1} \omega 7 c(47.82 \%)$ and iso- $\mathrm{C}_{15: 0} 2-\mathrm{OH}$ and/or $\mathrm{C}_{16: 1} \omega 7 c(14.1 \%$; the two fatty acids cannot be separated by GLC with the MIDI system). Spermidine is present as the major polyamine component, whereas agmatine, cadaverine, putrescine and spermine are detected only in small amounts.

The type strain, FR $1093^{\mathrm{T}}\left(=\mathrm{IMSNU} \quad 14133^{\mathrm{T}}=\mathrm{KCTC}\right.$ $12764^{\mathrm{T}}=$ JCM $14162^{\mathrm{T}}$ ), was isolated from surface seawater collected off Jeju Island, Republic of Korea.

\section{Acknowledgements}

This work was supported by the Korean Ministry of Science and Technology under the National Research Laboratory Program (R0A2005-000-10110-0). Y.W.L. was supported by the Korea Research Foundation (grant 2005-005-J16001).

\section{References}

Busse, H., El-Banna, T. \& Auling, G. (1989). Evaluation of different approaches for identification of xenobiotic-degrading pseudomonads. Appl Environ Microbiol 55, 1578-1583.

Busse, H.-J., Denner, E. B. M., Buczolits, S., Salkinoja-Salonen, M., Bennasar, A. \& Kampfer, P. (2003). Sphingomonas aurantiaca sp. nov., Sphingomonas aerolata sp. nov. and Sphingomonas faeni sp. nov., air- and dustborne and Antarctic, orange-pigmented, psychrotolerant bacteria, and emended description of the genus Sphingomonas. Int $J$ Syst Evol Microbiol 53, 1253-1260.

Chun, J. \& Goodfellow, M. (1995). A phylogenetic analysis of the genus Nocardia with 16S rRNA gene sequences. Int J Syst Bacteriol 45, 240-245.

Chun, J., Lee, J.-H., Jung, Y., Kim, M., Kim, S., Kim, B. K. \& Lim, Y.-W. (2007). EzTaxon: a web-based tool for the identification of prokaryotes based on $16 \mathrm{~S}$ ribosomal RNA gene sequences. Int J Syst Evol Microbiol 57, 2259-2261.
Cowan, S. T. \& Steel, K. J. (1965). Manual for the Identification of Medical Bacteria. London: Cambridge University Press.

Felsenstein, J. (1981). Evolutionary trees from DNA sequences: a maximum likelihood approach. J Mol Evol 17, 368-376.

Felsenstein, J. (1985). Confidence limits on phylogenies: an approach using the bootstrap. Evolution 39, 783-791.

Fitch, W. M. (1971). Toward defining the course of evolution: minimum change for a specific tree topology. Syst Zool 20, 406-416.

Flores, H. E. \& Galston, A. W. (1982). Analysis of polyamines in higher plants by high performance liquid chromatography. Plant Physiol 69, 701-706.

Godoy, F., Vancanneyt, M., Martinez, M., Steinbuchel, A., Swings, J. \& Rehm, B. H. (2003). Sphingopyxis chilensis sp. nov., a chlorophenoldegrading bacterium that accumulates polyhydroxyalkanoate, and transfer of Sphingomonas alaskensis to Sphingopyxis alaskensis comb. nov. Int J Syst Evol Microbiol 53, 473-477.

Jeon, Y. S., Chung, H., Park, S., Hur, I., Lee, J. H. \& Chun, J. (2005). jPHYDIT: a JAVA-based integrated environment for molecular phylogeny of ribosomal RNA sequences. Bioinformatics 21, 31713173.

Kämpfer, P., Witzenberger, R., Denner, E. B. M., Busse, H.-J. \& Neef, A. (2002). Sphingopyxis witflariensis sp. nov., isolated from activated sludge. Int J Syst Evol Microbiol 52, 2029-2034.

Komagata, K. \& Suzuki, K. (1987). Lipid and cell-wall analysis in bacterial systematics. Methods Microbiol 19, 161-207.

Lee, J.-S., Shin, Y. K., Yoon, J.-H., Takeuchi, M., Pyun, Y.-R. \& Park, Y.-H. (2001). Sphingomonas aquatilis sp. nov., Sphingomonas koreensis sp. nov. and Sphingomonas taejonensis sp. nov., yellow-pigmented bacteria isolated from natural mineral water. Int J Syst Evol Microbiol 51, 1491-1498.

Lyman, J. \& Fleming, R. H. (1940). Composition of sea water. J Mar Res 3, 134-146.

Minnikin, D. E., O’Donnell, A. G., Goodfellow, M., Alderson, G., Athalye, M., Schaal, A. \& Parlett, J. H. (1984). An integrated procedure for the extraction of bacterial isoprenoid quinones and polar lipids. J Microbiol Methods 2, 233-241.

Saitou, N. \& Nei, M. (1987). The neighbor-joining method: a new method for reconstructing phylogenetic trees. Mol Biol Evol 4, 406425.

Stackebrandt, E. \& Goebel, B. M. (1994). Taxonomic note: a place for DNA-DNA reassociation and 16S rRNA sequence analysis in the present species definition in bacteriology. Int J Syst Bacteriol 44, 846849.

Swofford, D. L. (1998). PAUP: Phylogenetic analysis using parsimony, version 4. Sunderland, MA: Sinauer Associates.

Takeuchi, M., Kawai, F., Shimada, Y. \& Yokota, A. (1993). Taxonomic study of polyethylene glycol-utilizing bacteria: emended description of the genus Sphingomonas and new descriptions of Sphingomonas macrogoltabidus sp. nov., Sphingomonas sanguis sp. nov. and Sphingomonas terrae sp. nov. Syst Appl Microbiol 16, 227-238.

Takeuchi, M., Hamana, K. \& Hiraishi, A. (2001). Proposal of the genus Sphingomonas sensu stricto and three new genera, Sphingobium, Novosphingobium and Sphingopyxis, on the basis of phylogenetic and chemotaxonomic analyses. Int J Syst Evol Microbiol 51, 1405-1417.

Vancanneyt, M., Schut, F., Snauwaert, C., Goris, J., Swings, J. \& Gottschal, J. C. (2001). Sphingomonas alaskensis sp. nov., a dominant bacterium from a marine oligotrophic environment. Int J Syst Evol Microbiol 51, 73-79.

Wayne, L. G., Brenner, D. J., Colwell, R. R., Grimont, P. A. D., Kandler, O., Krichevsky, M. I., Moore, L. H., Moore, W. E. C., Murray, R. G. E. \& other authors (1987). International Committee on Systematic 
Bacteriology. Report of the ad hoc committee on reconciliation of approaches to bacterial systematics. Int J Syst Bacteriol 37, 463-464.

Yabuuchi, E., Kosako, Y., Fujiwara, N., Naka, T., Matsunaga, I., Ogura, H. \& Kobayashi, K. (2002). Emendation of the genus Sphingomonas Yabuuchi et al. 1990 and junior objective synonymy of the species of three genera, Sphingobium, Novosphingobium and Sphingopyxis, in conjunction with Blastomonas ursincola. Int J Syst Evol Microbiol 52, 1485-1496.

Yi, H. \& Chun, J. (2006). Thalassobius aestuarii sp. nov., isolated from tidal flat sediment. J Microbiol 44, 171-176.
Yi, H., Oh, H.-M., Lee, J.-H., Kim, S.-J. \& Chun, J. (2005). Flavobacterium antarcticum sp. nov., a novel psychrotolerant bacterium isolated from the Antarctic. Int J Syst Evol Microbiol 55, 637-641.

Yoon, J.-H. \& Oh, T.-K. (2005). Sphingopyxis flavimaris sp. nov., isolated from sea water of the Yellow Sea in Korea. Int J Syst Evol Microbiol 55, 369-373.

Yoon, J.-H., Lee, C.-H., Yeo, S.-H. \& Oh, T.-K. (2005). Sphingopyxis baekryungensis sp. nov., an orange-pigmented bacterium isolated from sea water of the Yellow Sea in Korea. Int J Syst Evol Microbiol 55, 1223-1227.

ZoBell, C. E. (1941). Studies on marine bacteria. I. The cultural requirements of heterotrophic aerobes. J Mar Res 4, 42-75. 